\title{
Autoimmune hemolytic anemia
}

INSERM

\section{Source}

INSERM. (1999). Orphanet: an online rare disease and orphan drug data base.

Autoimmune hemolytic anemia. ORPHA:98375

Autoimmune hemolytic anemia (AIHA) is an autoimmune disorder in which various types

of auto-antibodies are directed against red blood cells causing their survival to be shortened and resulting in hemolytic anemia. 